\title{
Distribution of grasses along an altitudinal gradient in a Venezuelan paramo
}

\author{
Distribución de gramíneas a lo largo de un gradiente altitudinal en un páramo \\ de Venezuela
}

\section{EDJULY J. MÁRQUEZ, ${ }^{1}$ MARIO R. FARIÑAS ${ }^{2}$, BENITO BRICEÑO³ \& FERMÍN J. RADA ${ }^{2}$}

\author{
${ }^{1}$ Postgrado en Ecología Tropical, Instituto de Ciencias Ambientales y Ecológicas, Facultad de Ciencias, \\ Universidad de Los Andes, Mérida 5101, Venezuela \\ ${ }^{2}$ Instituto de Ciencias Ambientales y Ecológicas, Facultad de Ciencias, Universidad de Los Andes, Mérida 5101, Venezuela \\ ${ }^{3}$ Departamento de Biología, Facultad de Ciencias, Universidad de Los Andes, Mérida 5101, Venezuela \\ Corresponding author: e-mail: july@ula.ve
}

\begin{abstract}
In Venezuelan paramos grasses, after Asteraceae, are the second family in numerical importance. We studied their distribution in an altitudinal gradient located in Venezuela, Sierra de La Culata, between 2,500 and $4,200 \mathrm{~m}$ of altitude. Twenty one $32 \mathrm{~m}$ parallel line transects every $50 \mathrm{~m}$ were placed along the gradient, perpendicular to the main slope. Each line was divided into contiguous 50 x $50 \mathrm{~cm}$ sampling units. Grass species occurrence inside each sample unit was considered to determine their frequency in each line or altitude. The peak and altitudinal amplitude was determined through the weighted averaging method. A total of 47 grass species were found along the gradient. Agrostis was the best-represented genus in the gradient. Considering the distribution ranges, we assume that there are different biotic and abiotic processes determining the distribution patterns. The species occurring at the highest altitudes were temperate elements, while those in the lowest areas were tropical and subtropical elements. Seven species in the gradient are endemic to the Venezuelan paramos. Grass distribution patterns in the paramo may be related to phytogeographical origin. In order to better understand the plant altitudinal distribution pattern is necessary to consider the plant responses to low temperatures, high incoming radiation, water stress and slope aspect.
\end{abstract}

Key words: altitudinal patterns, phytogeography, Poaceae, South American Andes, tropical high mountain.

\section{RESUMEN}

En los páramos de Venezuela las gramíneas son la segunda familia numéricamente más importante, después de las Asteraceae. Nosotros estudiamos su distribución en un gradiente altitudinal ubicado en Venezuela, Sierra de La Culata, entre 2.500 y $4.200 \mathrm{~m}$ de altitud. Para esto colocamos 21 transectas de $32 \mathrm{~m}$ de longitud a lo largo del gradiente, ubicados de manera perpendicular a la pendiente, cada $50 \mathrm{~m}$ en altitud. Cada transecta estaba dividida en unidades de muestreo contiguas de 50 × $50 \mathrm{~cm}$. Para estimar la frecuencia de las especies en cada transecta o altitud, consideramos la ocurrencia de las mismas dentro de cada una de las unidades de muestreo. Determinamos el óptimo y la amplitud altitudinal a través del método de los promedios ponderados. Encontramos un total de 47 especies de gramíneas distribuidas a lo largo del gradiente. Agrostis fue el género mejor representado. Teniendo en cuenta los intervalos de distribución, podemos asumir que hay diferentes procesos que determinan la distribución de las especies, pudiendo estos ser de origen biótico y abiótico. Las especies que ocurren a mayores altitudes correspondieron a elementos templados, mientras que aquellos que ocurren en áreas de menor altitud fueron elementos tropicales y subtropicales. Siete de las especies del gradiente son endémicas a los páramos de Venezuela. Los patrones de distribución de las gramíneas en el páramo, parecen estar relacionados con el origen fitogeográfico. Para entender mejor los determinantes de los patrones de distribución altitudinal es necesario considerar las relaciones existentes entre las respuestas de las especies a las bajas temperaturas, radiación, estrés hídrico y exposición.

Palabras clave: patrones altitudinales, fitogeografía, Poaceae, Andes suramericanos, alta montaña tropical. 


\section{INTRODUCTION}

The distribution of a species is the result of physiological adaptation to biotic and environmental conditions, and to evolutionary events (Clayton 1981, Ricardi et al. 1997, Sklenár̂ \& Jørgensen 1999, Sklenár̂ \& Ramsay 2001). Gates (1980) considers temperature and humidity as the main determinants of distribution patterns in grasslands. In the particular case of South America Andean Mountains, species distribution has been influenced greatly by both tectonic and climatic dynamics (van der Hammen 1988).

The highlands in Venezuela are represented by paramo, a Neotropical ecosystem between the timberline and the snowline (Smith 1994, Luteyn 1999), with particular features such as: low ambient temperatures, higher daily temperature oscillations than seasonal ones, and a high frequency of night frost throughout the year (Cuatrecasas 1968, Monasterio 1980a, Baruch 1982, Sarmiento 1986).

Rosettes and grasses are the main growth forms in the Venezuelan paramos (Hedberg \& Hedberg 1979, Fariñas \& Monasterio 1980, Monasterio 1980a, 1980b). Rosettes have been well studied. For instances: radiation and distribution (Cuatrecasas 1986, Monasterio \& Sarmiento 1991), population dynamics (Estrada \& Monasterio 1988), and adaption to cold environments (Meinzer \& Goldstein 1985, Rada et al. 1985, Monasterio 1986, Rada et al. 1987, Meinzer et al. 1994). But grasses, the second family in numerical importance after the Asteraceae (Luteyn et al. 1992, Briceño \& De Robert 1996, Ricardi et al. 1997) have received less attention.

The common occurrence of grasses under cold environmental conditions has been reported (Teeri \& Stowe 1976, Clayton \& Renvoize 1986, Schwarz \& Redmann 1987, Sage \& Sage 2002). Clayton (1981) highlights the properties of some taxonomic groups in the Poaceae (Aveneae, Poeae and Stipeae) to adapt to cold conditions, either in high mountains or in temperate zones. Relationships between the distribution patterns in some subfamilies and tribes of the Poaceae and the environmental variables that determine such patterns have been established (Hartley 1958a, 1958b, 1961, 1973, Hartley \& Slater 1960). Low temperature resistance mechanisms for the Poaceae in the paramo evidence the adaptation of some species in the family to these environmental conditions (Márquez 2002).

Researchers have related the distribution of plant species, including grasses, in the paramo, with temperature (Baruch 1984, Ricardi et al. 1987, Fariñas \& Monasterio 1998, Luteyn 1999, Sklenáø \& Jørgensen 1999), and biogeographic aspects (van der Hammen \& Cleef 1986, Monasterio \& Sarmiento 1991, Ricardi et al. 1997). In all these studies, the authors consider the altitudinal distribution of plants based on the presence of the species and not their frequency.

At present, paramos are under increasing antropic pressures. In this sense, Grytnes (2003) points out the importance in understanding altitudinal species patterns for the management of species diversity. The aim of this study is to understand the altitudinal distribution of paramo grasses.

\section{MATERIAL AND METHODS}

\section{Study area}

The paramo has $2,000 \mathrm{~m}$ of altitudinal extension (Monasterio 1980a). We studied a $1,700 \mathrm{~m}$ altitudinal transect, located in Sierra de La Culata, Mérida, Venezuela (851'04" N,

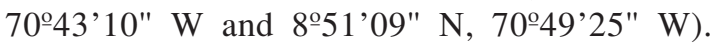
We selected an east-facing slope characterized by a unimodal precipitation pattern. Both precipitation and temperature decrease as altitude increases (Fig. 1). The number of days with frost increases with altitude and during the dry season (Monasterio \& Reyes 1980).

The highest zone in the gradient shows a high and open rosette paramo vegetation defined as desert paramo by Monasterio (1979, 1980a). At this altitude, the vegetation cover is spatially patched and is mainly composed by woody and herbs perennial species, predominantly tall rosettes and cushions (Monasterio 1980a). Grasses have low frequencies and occupy the lowest stratum, often represented by cushion forms. The middle part of the gradient (around 3,500 $\mathrm{m}$ of altitude) has three strata, the lowest and middle ones are occupied by grasses (covering 40 and $80 \%$, respectively) and herbs (Fariñas \& Monasterio 1980). Rosettes and shrubs occupy the highest stratum. Finally, in 
the lowest zone of the gradient, the vegetation is a mixture of rosettes, grasses, herbs and shrubs (Monasterio \& Reyes 1980), all of them forming a continuous vegetation cover and occupying all strata.

In general terms, soils in the paramo are relatively young and have been under the effect of glaciations (Schubert 1976, 1981, Hooghiemstra 1989). Moreover, soils are often acidic and poorly developed with a low content of inorganic nutrients (Baruch 1979, 1982), high content of organic carbon and total nitrogen, and low water holding capacity (Fariñas 1975).

\section{Grass distribution sampling}

Grass distribution was studied along a gradient between 2,500 and 4,200 $\mathrm{m}$ of altitude including the following locations: El Baho, Las Tapias, Paso Real Hotel, Los Plantíos, Pico El Gavilán, and Pico El Águila (Fig. 2).
Twenty-one lines of $32 \mathrm{~m}$ in length were placed along the gradient, arranged perpendicular to the main slope, and located every $50 \mathrm{~m}$ of altitude (sampling was not possible at some altitudes due to difficult access or antropic disturbed conditions). Each line was divided into contiguous $50 \times 50 \mathrm{~cm}$ sampling units. Grass species occurrence inside each sample unit was considered to determine their frequency in each line or altitude. Finally, the peak and altitudinal amplitude was determined through the weighted averaging method (Ellenberg 1979, ter Braak \& Barendregt 1986) using the following equations, for the optimum:

$$
\hat{V}_{i k}=\frac{\sum_{j=1}^{m} \mathrm{Ae}_{i j} \mathrm{VA}_{\mathrm{kj}}}{\sum_{j=1}^{\mathrm{m}} \mathrm{Ae}_{\mathrm{ij}}}
$$

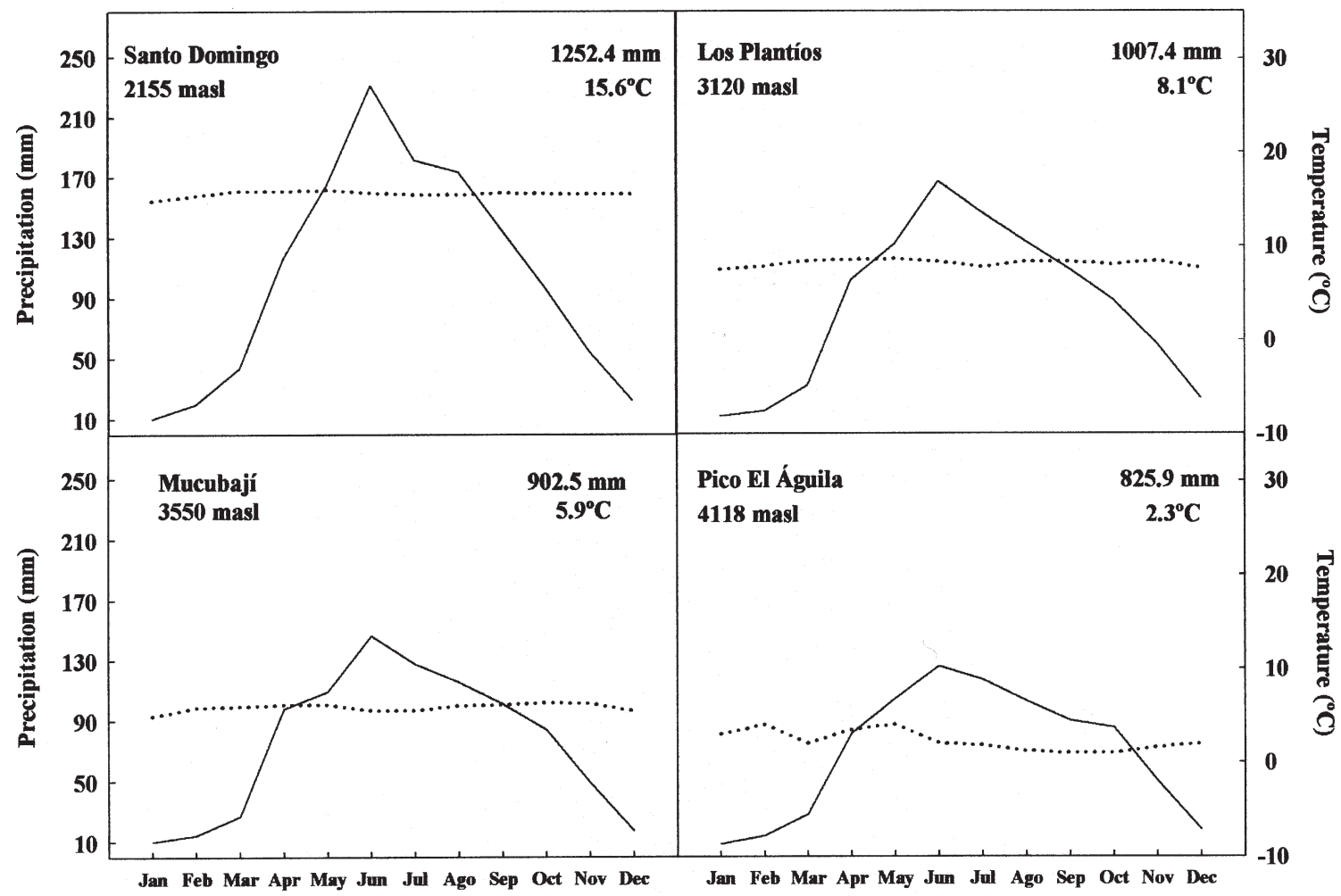

Fig. 1: Mean precipitation and temperature (1960-1995) at different altitudes. There is a decrease in both environmental variables as altitude increases (Ministerio del Ambiente y Recursos Naturales Renovables, Dirección de Hidrología y Meteorología).

Promedios de precipitación y temperatura (1960-1995) a diferentes altitudes. Se aprecia una disminución de ambas variables ambientales a medida que la altitud se incrementa (Ministerio del Ambiente y Recursos Naturales Renovables, Dirección de Hidrología y Meteorología). 


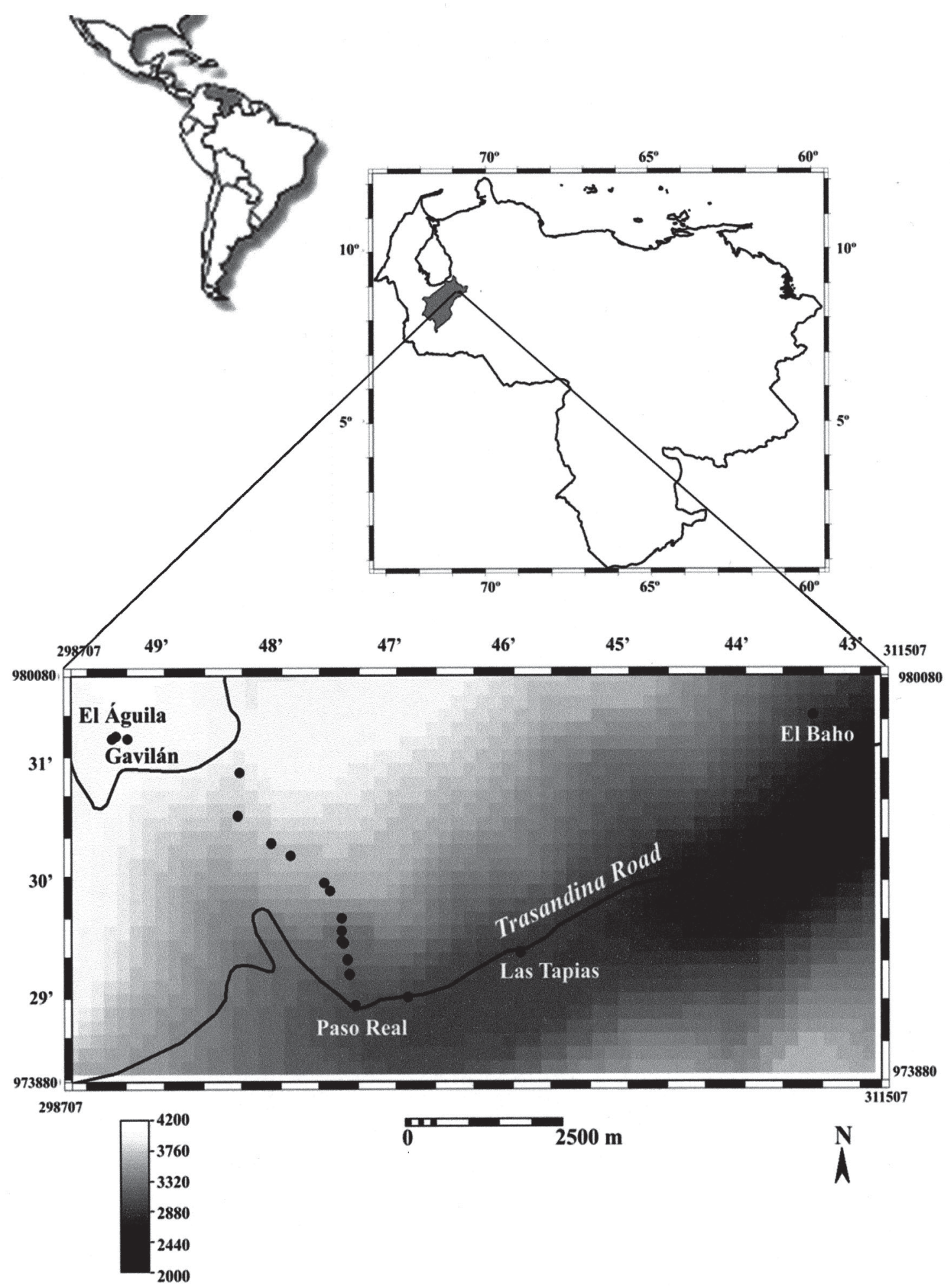

Fig. 2: Spatial location of the study area (UTM coordinates at corners correspond to 19N Zone). The filled circles indicate the studied locations in the altitudinal gradient.

Ubicación especial del área de estudio (las coordenadas UTM localizadas en las esquinas corresponden a la Zona 19N). Los círculos negros indican los puntos de muestreo en el gradiente. 
$\hat{V} I_{\mathrm{ik}}$ is the weighted averaging of species $i$ for factor $k$ (altitude). $A e_{i j}$ is species $i$ abundance at place $j . \mathrm{VA}_{\mathrm{kj}}$ is environmental variable $k$ at place $j$, and $m$ is the number of sample units. On the other hand, altitudinal amplitude was calculated as follows:

$$
t_{i k}=\sqrt{\frac{\sum_{i=1}^{m} A e_{i j}\left(V A_{k j}-\hat{V I}_{i k}\right)^{2}}{\sum_{i=1}^{m} A e_{i j}}}
$$

where $\mathrm{t}_{\mathrm{ik}}$ is species $i$ amplitude to factor $k, \mathrm{Ae}_{\mathrm{ij}}$ is species $i$ abundance at place $j, \mathrm{VA}_{\mathrm{kj}}$ is environmental variable $k$ at place $j, \hat{V} \mathrm{I}_{\mathrm{ik}}$ is the weighted averaging for species $i$ to factor $k$ and $m$ is the number of observed lines.

Samples were taken in August 2001, during the rainy season to guarantee flowering of as many grass species as possible. Individuals were taken to the lab, pressed and dried for later botanical determinations according to Hitchcock (1927), Luces (1953), Rosengurtt et al. (1970), Pohl (1980), Tovar (1993), Briceño \& Morillo (1994), and Davidse et al. (1994). The Clayton \& Renvoize (1986) tribal division was applied. Bouchers were placed in the Herbarium MER of the Facultad de Ciencias Forestales y Ambientales, Universidad de Los Andes.

\section{RESULTS}

Forty seven species were found along the gradient (Fig. 3). Some species were located just at one altitude (indicated as a black circle in Fig. 4), as well as species with wide and restricted distributions. Species located at one altitude were common at the extremes of the gradient, whereas wide distributions were found in the middle of the gradient. Some species support the hypothesis that unimodal distribution and symmetry is not common showing truncated distributions (Fig. 4). The following species: Sporobolus indicus, Vulpia bromoides, Axonopus fissifolius, Trisetum kochianum, T. pringlei, Muhlenbergia venezuelae, Nassella mexicana, Trisetum deyeuxoides, Poa petrosa, Agrostis basalis and A. breviculmis show a narrow distribution in the gradient. The opposite is true for Pennisetum clandestinum, Aegopogon cenchroides, Trisetum irazuense, Paspalum pilgerianum, Poa annua, Nassella linearifolia, Agrostis tolucensis, Calamagrostis pittieri, Agrostis trichoides and Aciachne acicularis.

Taking into account the complete gradient, there was a substitution of species forming a continuum along the altitudinal gradient (Fig. 4). Agrostis was the richest genus in the gradient with six species, followed by Festuca and Trisetum with five species each. Agrostis basalis, Agrostis breviculmis, Bromus catharticus and Calamagrostis heterophylla were found exclusively above 4,000 $\mathrm{m}$ of altitude. Other species were restricted to the middle and lower zones of the gradient. Calamagrostis pisinna, Cortaderia hapalotricha, Festuca pinetorum, and Paspalum pygmaeum were only collected outside of the sampling units.

The species found belong to 10 tribes (Table 1): Arundineae (two species), Aveneae (16 species), Bromeae (two species), Cynodonteae (one species), Eragrostideae (three species), Meliceae (one species), Paniceae (six species), Poeae (11 species), Stipeae (four species), and Triticeae (one species). Poeae and Aveneae are the most important tribes in terms of number of species, which include wide temperate elements (van der Hammen \& Cleef 1986). Eragrostideae is the only tribe with a tropical origin (Clayton \& Renvoize 1986), distributed between 2,445 and $3,675 \mathrm{~m}$ of altitud with a mixture of species belonging to endemic (Muhlenbergia venezuelana), holartic (M. ligularis), and wide tropical elements (van der Hammen \& Cleef 1986). The Cynodonteae, Meliceae, and Paniceae tribes had tropical and subtropical origins (Gould \& Shaw 1983, Clayton \& Renvoize 1986, van der Hammen \& Cleef 1986), with a similar distribution to that of Eragrostideae, between 2,470 and 3,550 m of altitude. On the other hand, Arundineae, with austral-antarctic (Cortaderia hapalotricha) and wide temperate (Danthonia secundiflora) elements (van der Hammen \& Cleef 1986), Bromeae and Poeae tribes, with wide temperate elements (Gould \& Shaw 1983, Clayton \& Renvoize 1986, van der Hammen \& Cleef 1986), were distributed between 2,470 and 3,980 $\mathrm{m}$ of altitude. Aveneae, Stipeae, and Triticeae showed wide temperate elements, typically from high altitudes (Clayton \& Renvoize 1986, van der Hammen \& Cleef 
1986), and were distributed between 2,470 and $4,180 \mathrm{~m}$ of altitude. These last tribe groups reached the highest elevations in the gradient.

Aciachne is the only genus endemic to the Andean region including Central and South America, while there are seven species endemic to Venezuelan paramos (14.9\%): Agrostis basalis, A. jahni, A. meridensis, Muhlenbergia venezuelae, Festuca elviae, F. fragilis, and Poa petrosa, four of them found above $3,800 \mathrm{~m}$ of altitude (Fig. 4). There are eight introduced species, representing $17 \%$ of the total: Polypogon monspeliensis, from Eurasia, Trisetum spicatum, Lolium perenne, and Poa annua, natives from Europe, Panicum trichoides, from Africa and Asia, Pennisetum clandestinum, native of tropical Africa, and Vulpia bromoides and V. myuros, natives of Eurasia and North Africa. Thirty-eight species found in the gradient were native of America (Table 1).

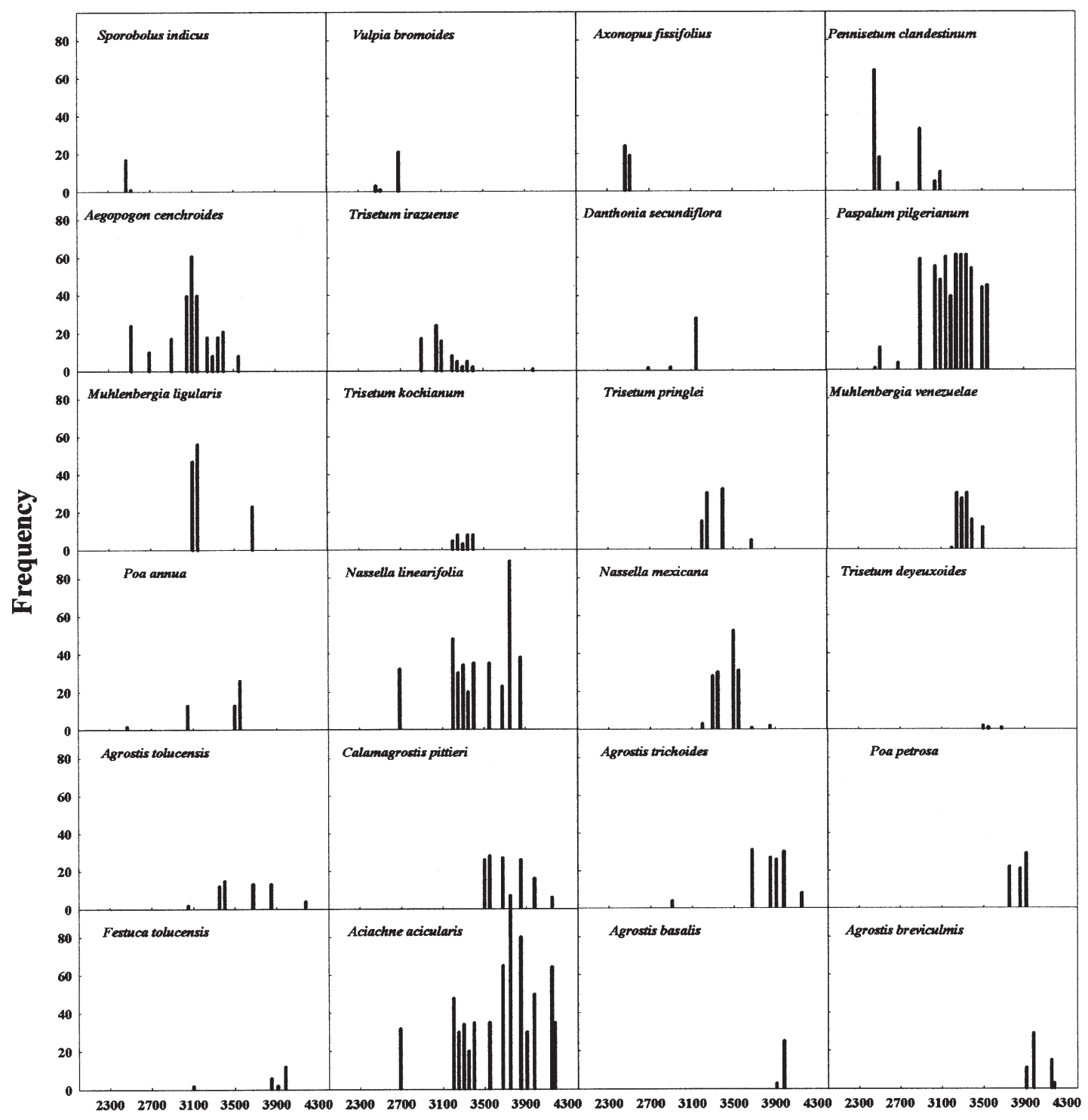

\section{Altitude (m)}

Fig. 3: Species frequency at each altitude. Species found at more than one altitude were considered. Note the distributions pattern, which may or not be symmetrical.

Frecuencia de las especies a cada altitud. Se consideraron aquellas especies localizadas en más de una altitud. Nótese la forma de las distribuciones, las cuales pueden ser simétricas o no. 


\section{TABLE 1}

Species found in the studied gradient. Tribes with their phytogeographical element, species observed distribution range and altitudinal optimum calculated through the weighted averaging method: afrom Clayton \& Renvoize (1986); baccording van der Hammen \& Cleef (1986); ${ }^{\text {cfrom }}$ Hitchcock (1927), Luces (1953), Rosengurtt et al. (1970), Pohl (1980), Tovar (1993), Briceño \& Morillo (1994), Davidse et al. (1994), and Luteyn (1999); ${ }^{\mathrm{d}}$ from Gould \& Shaw (1983); ${ }^{\mathrm{e}}$ species found outside the sample units

Especies encontradas en el gradiente estudiado. Se muestran las tribus con su elemento fitogeográfico, así como los intervalos y óptimos de distribución de las especies, calculados a través del método de los promedios ponderados: ${ }^{a}$ Clayton \& Renvoize (1986); ${ }^{\mathrm{b}}$ van der Hammen \& Cleef (1986); ${ }^{\mathrm{c}}$ según Hitchcock (1927), Luces (1953), Rosengurtt et al. (1970),

Pohl (1980), Tovar (1993), Briceño \& Morillo (1994), Davidse et al. (1994) y Luteyn (1999); dGould \& Shaw (1983); e especies encontradas fuera de las unidades de muestreo

\begin{tabular}{|c|c|c|c|c|c|}
\hline \multirow[t]{2}{*}{ Tribe $^{\mathrm{a}}$} & \multirow[t]{2}{*}{ Phytogeographic element ${ }^{b}$} & \multirow[t]{2}{*}{ Species } & \multicolumn{2}{|c|}{ Altitudinal } & \multirow{2}{*}{$\begin{array}{l}\text { Present geographical } \\
\text { distribution }^{c}\end{array}$} \\
\hline & & & Range (m) & Optimum (m) & \\
\hline \multirow[t]{2}{*}{ Arundineae } & Neotropical & Cortaderia hapalotricha Pilg.e & - & - & $\mathrm{CR}$ to BO \\
\hline & Wide temperate & Danthonia secundiflora J. Presl. & $2,690-3,150$ & 3,106 & CO EC PE BR AR \\
\hline \multirow[t]{16}{*}{ Aveneae } & Endemic & Agrostis basalis Luces & $3,910-3,980$ & 3,973 & VE \\
\hline & & Agrostis jahni Luces & 3,100 & 3,100 & $\mathrm{VE}$ \\
\hline & & Agrostis meridensis Luces & 3,910 & 3,910 & VE \\
\hline & Wide temperate & Agrostis breviculmis Hitchc & $3,910-4,180$ & 4,021 & CO EC PE BO CH \\
\hline & & Agrostis tolucensis Kunth & $3,050-4,180$ & 3,593 & ME to $\mathrm{CH}$ \\
\hline & & Agrostis trichodes (Kunth) Roem. \& Schult. & $2,905-4,150$ & 3,839 & CO EC PE \\
\hline & & Calamagrostis heterophylla (Wedd.) Pilg. & 4,150 & 4,150 & EC PE BO \\
\hline & & Calamagrostis pisinna Swallene & - & - & $\mathrm{CO}$ \\
\hline & & Calamagrostis pittieri Hackel & $3,500-4,150$ & 3,707 & CR CO \\
\hline & & Polypogon elongatus Kunth & 2,470 & 2,470 & ME to AR BO \\
\hline & & Polypogon monspeliensis (L.) Desf & 2,470 & 2,470 & Native from Eurasia \\
\hline & & Trisetum deyeuxoides (Kunth) Kunth & $3,500-3,675$ & 3,556 & $\mathrm{ME}$ to $\mathrm{EC}$ \\
\hline & & Trisetum irazuense (Kuntze) A. Hitchc. & $2,905-3,980$ & 3,102 & ME to EC \\
\hline & & Trisetum kochianum Hern. & $3,200-3,400$ & 3,309 & ME GU CR \\
\hline & & Trisetum pringlei (Scribner ex Beal) A. Hitch. & $3,200-3,675$ & 3,325 & $S$ of ME CR PA \\
\hline & & Trisetum spicatum (L.) K. Richter & 2,905 & 2,905 & Native from Europe \\
\hline \multirow[t]{2}{*}{ Bromeae } & Wide temperate & Bromus catharticus Vahl & 3,980 & 3,980 & $\mathrm{~S}$ of USA to CH AR \\
\hline & & Bromus lanatus Kunth & 2,905 & 2,905 & CO EC PE BO CH \\
\hline Cynodonteae & Tropical and subtropical $^{d}$ & Aegopogon cenchroides Humb. \& Bompl. ex Willd & $2,515-3,550$ & 3,099 & $\begin{array}{l}\text { USA ME Antillas Mesoamerica to } \\
\text { BO BR }\end{array}$ \\
\hline \multirow[t]{3}{*}{ Eragrostideae } & Endemic & Muhlenbergia venezuelae Luces & $3,200-3,500$ & 3,334 & VE \\
\hline & Holartic & Muhlenbergia ligularis (Hackel) Hitchcock & $3,100-3,675$ & 3,227 & GUA CO to BO AR \\
\hline & Wide tropical & Sporobulus indicus (L.) R. Br. & $2,445-2,511$ & 2,478 & USA Antillas \\
\hline Meliceae & Tropical and subtropical ${ }^{d}$ & Triniochloa stipoides (Kunth) A. Hitchc. & 3,150 & 3,150 & ME to BO N of BR \\
\hline \multirow[t]{6}{*}{ Paniceae } & Neotropical & Axonopus fissifolius (Raddi) Kuhlm & $2,470-2,515$ & 2,534 & $\begin{array}{l}\text { Native from American tropics and } \\
\text { subtropics }\end{array}$ \\
\hline & & Paspalum pilgerianum Chase & $2,470-3550$ & 3,225 & CO EC PE \\
\hline & Tropical and subtropical $^{\mathrm{d}}$ & Panicum trichoides Swartz & 2,615 & 2,615 & Africa and Asia \\
\hline & & Pennisetum clandestinum Hochst. ex Chiov & $2,470-3,100$ & 2,672 & Native from tropical Africa \\
\hline & Wide tropical & Paspalum inconstans Chase & 2,615 & 2615 & CO EC PE BO \\
\hline & & Paspalum pygmaeum Hackel $^{e}$ & - & - & PE BO \\
\hline \multirow[t]{11}{*}{ Poeae } & Endemic & Festuca elviae Briceño & 3,100 & 3,100 & VE \\
\hline & & Festuca fragilis (Luces) Briceño & 3,910 & 3,910 & VE \\
\hline & & Poa petrosa Swallen & $3,750-3,910$ & 3,842 & VE \\
\hline & Wide temperate & Festuca pinetorum Swallen ${ }^{\mathrm{e}}$ & . & - & ME \\
\hline & & Festuca tolucensis Kunth & $3,100-3,980$ & 3,858 & ME to CR CO \\
\hline & & Festuca ulochaeta Steudel & 3,550 & 3,550 & EC PE BO BR AR \\
\hline & & Роа аппиа $\mathrm{L}$. & $2,470-3,550$ & 2,690 & Native from Europe \\
\hline & & Poa aequatorensis Hackele & - $\quad$ & - & EC PE \\
\hline & & Lolium perenne $\mathrm{L}$. & 2,905 & 2,905 & Native from Europe \\
\hline & & Vulpia bromoides (L.) Gray & $2,470-2,515$ & 2,506 & Eurasia and $\mathrm{N}$ Africa \\
\hline & & Vulpia myuros (L.) Gmelin ${ }^{\mathrm{e}}$ & & - & Eurasia and $\mathrm{N}$ Africa \\
\hline \multirow[t]{4}{*}{ Stipeae } & Neotropical & Aciachne acicularis Lægaard & $3,675-4,180$ & 3,966 & CR to $\mathrm{CO}$ \\
\hline & Wide temperate & Nassella linearifolia (Fourn.) R. Pohl & $2,690-3,850$ & 3,426 & $\mathrm{~S}$ of ME Mesoamerica CO BO \\
\hline & & Nassella mexicana (A. Hitchc.) R. Pohl & $3,200-3,850$ & 3,442 & ME to BO \\
\hline & & Nassella mucronata (Kunth) R. Pohl & 2,905 & 2,905 & ME to AR BO \\
\hline Triticeae & Wide temperate & Brachypodium mexicanum (Roem. \& Schult.) Link & 2,690 & 2,690 & ME to BO \\
\hline
\end{tabular}

$\mathrm{AR}=$ Argentina; $\mathrm{BO}=$ Bolivia; $\mathrm{BR}=$ Brasil; $\mathrm{CH}=$ Chile $\mathrm{CO}=$ Colombia; $\mathrm{CR}=$ Costa Rica; $\mathrm{EC}=$ Ecuador; GUA = Guatemala; $\mathrm{GU}=$ Guyana; $\mathrm{ME}=$ México; $\mathrm{PA}=$ Panamá; $\mathrm{PE}=$ Perú; $\mathrm{VE}=$ Venezuela 


\section{DISCUSSION}

Some authors have argued that grasses are an important element of paramo vegetation (Monasterio 1980a, Fariñas \& Monasterio 1980, 1998, Baruch 1984, Luteyn et al. 1992, Ricardi et al. 1997). Our results support these observations, since grasses were found at all studied altitudes. Simpson \& Todzia (1990) suggest that their success, as in the Asteraceae, must be due to dispersion mechanisms, often facilitated by wind action (Jacobs 1999) and animal transportation. However, the occurrence of grasses become patchily distributed as altitude increases, an observation that contrasts with the more continuum pattern observed at lower elevations, and that seems associated to climatic constraints (Sklenár̂ \& Ramsay 2001). Palynological information obtained in Colombia suggests that the Poaceae have been an important element of paramo vegetation since the Pleistocene (Salgado-Labouriau 1978, van der Hammen \& Cleef 1986, van der Hammen 1988, Behling et al. 1998, Marchant et al. 2001). However, there is no accurate information on the grass genera that occupied

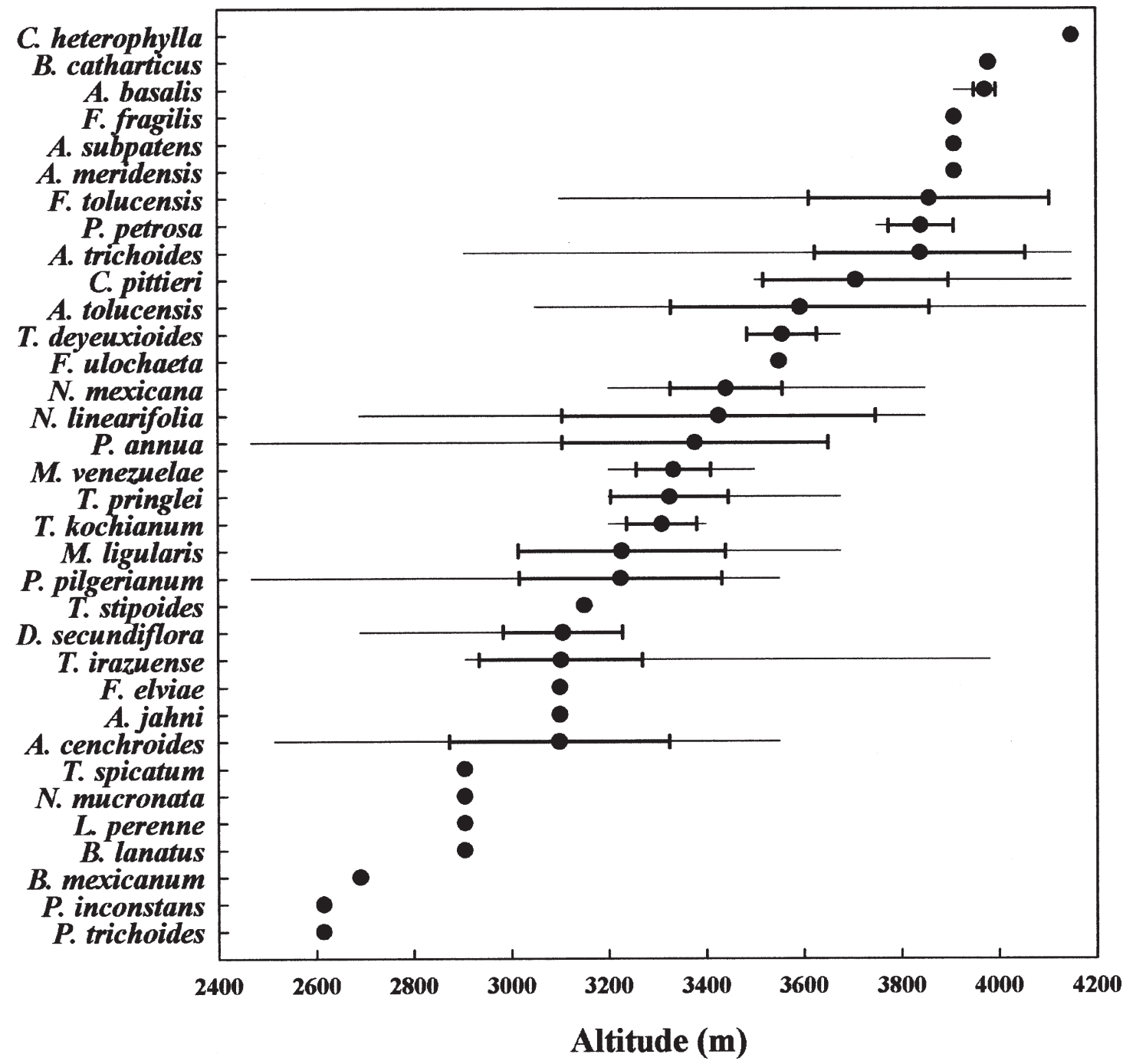

Fig.4: Species distribution in the altitudinal gradient. Species altitudinal optimum occurrence $(\bullet)$, the calculated amplitude $(\mapsto)$,observed altitudinal limits $(-)$.

Distribución de las especies en el gradiente altitudinal. óptimo altitudinal de las especies $(\bullet)$, amplitud calculada $(\mapsto)$ y límites altitudinales observados (-). 
the paramos. It is not well understood what determines the amplitude of different species in the paramo. Körner (1992) proposed a mixture of processes defining the spatial pattern: at lower elevations prevail biotic processes, such as competition by light, water, nutrients and space, and at higher elevations prevail abiotic processes all of them conditioned by severe environmental conditions, such as freezing temperatures and water stress.

Some species mentioned in this study have been reported by other authors working in other paramos: Ricardi et al. (1987) found Agrostis breviculmis, A. meridensis, A. tolucensis, Bromus pitensis (syn. B. lanatus Kunth), Calamagrostis mulleri (syn. C. heterophylla (Wedd.) Pilg.), Festuca tolucensis, Muhlenbergia ligularis, Poa annua, P. petrosa, Nassella mexicana, Trisetum irazuense, and $T$. spicatum in the Piedras Blancas paramo, at $4,200 \mathrm{~m}$ of altitude. This paramo is both drier and higher compared to our study site, suggesting that these species can resist more extreme conditions than those found in our study area. All these species belong to the Pooideae subfamily, which according to Clayton (1981) represents a new venture for the grasses due to their adaptation to cold climates. On the other hand, probably most grass species in the paramo arose recently because most of them (35 species out of $47.74 \%$ ) are native to America, which could be an evidence of active speciation processes. Endemism in grass species along the gradient is high $(14.9 \%)$ with respect to genera of vascular plants reviewed by van der Hammen \& Cleef (1986) in the eastern Colombian cordillera, representing only $7.3 \%$. These values could be interpreted as an evidence for active speciation in the Poaceae of the Northern Andes, since some genera such as Agrostis, Festuca and Poa with temperate origin are occurring in the gradient with endemic species (Agrostis jahni, A. meridensis, Festuca elviae, F. fragilis and Poa petrosa). Sklenár̂ \& Jørgensen (1999) found Agrostis breviculmis, Bromus catharticus, and Trisetum spicatum in the paramos of Ecuador. They also calculated the average and altitudinal amplitude, but they did not consider the pattern of species frequency along the gradient, only their extreme occurrence. Moreover, Baruch (1984) considered Calamagrostis mulleri and $C$. pittieri as high elevation species, and
Agrostis trichoides, Paspalum sp., and Aegopogon cenchroides as low paramo species. Similarly, Cabido et al. (1997) working in Córdoba, Argentina, found Agrostis breviculmis, A. tolucensis, and Muhlenbergia ligularis at the highest extreme of their gradient $(2,100 \mathrm{~m}$ of altitude). In this case, it is important to consider the altitudinal differences with respect to our gradient due to latitudinal differences. The distribution of Poa was studied with a botanical approach at a global scale by Hartley (1961), and in the Venezuelan páramos by Briceño (1987). Hartley (1961) indicates that high frequencies in Poa species in both high latitudes and altitudes, suggest that temperature is closely related to distribution, and an adaptation to cold and temperate climates (Clayton 1981, Clayton \& Renvoize 1986). Márquez (2002) found that the main adaptation of grasses to cold environments is related to frost tolerance.

Aveneae, Poeae, Stipeae, and Triticeae are frequently found at high altitudes in the Andean region, as well as in temperate regions (Hartley 1973, Gould \& Shaw 1983, van der Hammen \& Cleef 1986). Their temperate origin probably facilitated the colonization of the tropical high mountain. Burkart (1975) emphasizes the boreal influence on paramo grasses due to the migration bridge represented by the Andean mountain range. The consequence of this high degree of migration is a low endemism in the Andean mountains with respect to Africa (Luteyn et al. 1992, Sklenár \& Ramsay 2001). In our case, the only endemic genus is Aciachne (Burkart 1975, Luteyn et al. 1992). On the other hand, the genus Bromus and Brachypodium are relatively scarce at high altitudes and latitudes (Hartley 1973). However, Bromus has relatively high frequencies in the paramo. Festuca is a genus with a long evolutionary history and it is believed that it has adapted easily to recent climatic conditions (Hartley 1973). Poa is the most interesting case in the Poaceae because it is a cosmopolitan genus, with temperate characters but present in tropical high mountains (Hartley 1973).

This study suggests that there is an important grass occurrence in the paramo with a temperate origin (49\%), as was mentioned by van der Hammen \& Cleef (1986) for paramo genera in the eastern Colombian cordillera and 
Ricardi et al. (1997) for Piedras Blancas in Venezuela. Therefore, the phytogeographic origin seems to determine, to a great extent, grass distribution in our transect. However, for a better understanding of the distribution pattern determinants it is necessary to study grass adaptative mechanisms to paramo climatic conditions (low temperatures, high incoming radiation, water stress).

Since Poaceae are highly sensitive to temperature and humidity changes (Berry \& Björkman 1980, Ehleringer \& Monson 1993), and to variations in environmental $\mathrm{CO}_{2}$ (Körner \& Diemer 1994, Street-Perrott et al. 1997) the study of their distribution patterns could be a powerful tool, which may help to understand aspects related with local climatic conditions, adaptations to environmental and vegetation responses to climatic changes. In this sense, if we consider the inverse of species amplitude as a measure of sensibility, those located in the extremes have to be specially taken into account for future research (Panicum trichoides, Paspalum inconstans, Brachypodium mexicanum, Bromus lanatus, $L$. perenne, N. mucronata, T. spicatum, at the lowest altitude, and $A$. meridensis, $A$. subpatens, $F$. fragilis, $A$. basalis, $C$. heterophylla, at the highest altitude). Studying grass distribution changes in time could be employed as a diagnostic method in studies of global change, as it would allow recording possible variations in altitudinal ranges in response to changes in environmental conditions.

\section{ACKNOWLEDGMENTS}

This project was supported by IAI (grant № CRN-040), FONACIT (grant № 98003404) and CDCHT (grant C-1090-01-01-E). We are grateful to $\mathrm{P}$. Alvizu for helping in the weighted averaging analysis, E. Chacón for map elaboration and A. Nieto and C. Erazo for their fieldwork assistance.

\section{LITERATURE CITED}

BARUCH Z (1979) Elevational differentiation in Espeletia schultzii (Compositae), a giant rosette plant of the Venezuelan paramos. Ecology 60: 85-98.

BARUCH Z (1982) Patterns of energy content in plants from the Venezuelan paramos. Oecologia 55: 47-52.

BARUCH Z (1984) Ordination and classification of vegetation along an altitudinal gradient in the Venezuelan paramos. Vegetatio 55: 115-126.

BEHLING H, A NEGRET \& H HOOGHIEMSTRA (1998) Late Quaternary vegetational and climatic change in the Popayán region, southern Colombian Andes. Journal of Quaternary Science 13: 43-53.

BERRY J \& O BJÖRKMAN (1980) Photosynthetic response and adaptation to temperature in higher plants. Annual Review of Plant Physiology 31: 491543.

BRICEÑO B (1987) El género Poa L. en el Páramo de Mucubají, Mérida-Venezuela. Revista de Ecología Latinoamericana (Venezuela) 1: 36-51.

BRICEÑO B \& G MORILLO (1994) El género Festuca L. (Poaceae) en los páramos de Mérida. Ernstia (Venezuela) 4: 73-88.

BRICEÑO B \& P DE ROBERT (1996) Diversidad y utilidad de las plantas vasculares en un páramo triguero de la Sierra Nevada de Mérida. Pittieria (Venezuela) 24: 43-61.

BURKART A (1975) Evolution of grasses and grasslands in South America. Taxon 24: 53-66.

CABIDO M, N ATECA, M ASTEGIANO \& A ANTON (1997) Distribution of $C_{3}$ and $C_{4}$ grasses along an altitudinal gradient in central Argentina. Journal of Biogeography 24: 197-204.

CLAYTON W (1981) Evolution and distribution of grasses. Annals of the Missouri Botanical Garden 68: $5-14$

CLAYTON W \& S RENVOIZE (1986) Genera Graminum: grasses of the world. Royal Botanical Gardens. Kew Bulletin Additional Series XIII. Her Majesty's Stationery Office, London, United Kingdom. 389 pp.

CUATRECASAS J (1968) Páramo vegetation and its life forms. Collections of Geography 9: 163-186.

CUATRECASAS J (1986) Speciation and radiation of the Espeletiinae in the Andes. In: Vuilleumier F \& M Monasterio (eds) High altitude tropical biogeography: 267-316. Oxford University Press, New York, New York, USA.

DAVIDSE G, M SOUSA \& A CHATER (1994) Flora mesoamericana. Missouri Botanical Garden, The Natural History Museum 6: 1-543.

EHLERINGER J \& R MONSON (1993) Evolutionary and ecological aspects of photosynthetic pathway variation. Annual Review of Ecology and Systematics 24: 411-439.

ELLENBERG H (1979) Zeigerwerte der gefässpflanzen mitteleuropas. Second edition. Scripta Geobotanica 9: 1-122 (with abstract in English).

ESTRADA C \& M MONASTERIO (1988) Ecología poblacional de una roseta gigante, Espeletia espicata Sch. Bip. (Compositae), del páramo desértico. Ecotrópicos (Venezuela) 1: 25-39.

FARIÑAS MR (1975) Análisis de la vegetación de páramo, ordenamiento y correlación con factores edáfico-climáticos. Trabajo de Ascenso, Facultad de Ciencias, Universidad de Los Andes, Mérida, Venezuela. 204 pp.

FARIÑAS MR \& M MONASTERIO (1980) La vegetación del páramo de Mucubají. Análisis de ordenamiento y su interpretación ecológica. In: Monasterio M (ed) Estudios ecológicos en los páramos andinos: 263-307. Universidad de Los Andes, Mérida, Venezuela.

FARIÑAS MR \& M MONASTERIO (1998) Ecología de Espeletia schultzii Wedd (Asteraceae) en el valle fluvioglacial del Páramo de Mucubají, Mérida, Venezuela. Actualidades Biológicas (Venezuela) 20: 5-11. 
GATES D (1980) Biophysical ecology. Springer-Verlag, New York, New York, USA. 611 pp.

GOULD FW \& RB SHAW (1983) Grass systematics. Second edition. Texas A\&M University Press, College Station, Texas, USA. 412 pp.

GRYTNES JA (2003) Species-richness patterns of vascular plants along seven altitudinal transects in Norway. Ecography 26: 291-300.

HARTLEY W (1958a) Studies on the origin, evolution, and distribution of the Gramineae. I. The tribe Andropogoneae. Australian Journal of Botany 6 : $115-128$.

HARTLEY W (1958b) Studies on the origin, evolution, and distribution of the Gramineae. II. The tribe Paniceae. Australian Journal of Botany 6: 343-357.

HARTLEY W (1961) Studies on the origin, evolution, and distribution of the Gramineae. IV. The genus Poa L. Australian Journal of Botany 9: 152-161.

HARTLEY W (1973) Studies on the origin, evolution, and distribution of the Gramineae. V. The subfamily Festucoideae. Australian Journal of Botany 21: 201234

HARTLEY W \& C SLATER (1960) Studies on the origin, evolution, and distribution of the Gramineae. III The tribes of the subfamily Eragrostoideae. Australian Journal of Botany 8: 256-276.

HEDBERG I \& O HEDBERG (1979) Tropical-alpine life forms of vascular plants. Oikos 33: 297-307.

HITCHCOCK A (1927) The grasses of Ecuador, Perú and Bolivia. Contributions from the National Herbarium 24: 291-556

HOOGHIEMSTRA H (1989) Quaternary and upperpliocene glaciations and forest development in the tropical Andes: evidence from a long highresolution pollen record from the sedimentary basin of Bogotá, Colombia. Palaeogeography, Palaeoclimatology, Palaeoecology 72: 11-26.

JACOBS BF (1999) The origin of grass-dominated ecosystems. Annals of Missouri Botanical Garden 86: 590-643.

KÖRNER C (1992) Response of alpine vegetation to global climate change. Catena 22: 85-96.

KÖRNER C \& M DIEMER (1994) Evidence that plants from high altitudes retain their greater photosynthetic efficiency under elevated $\mathrm{CO}_{2}$. Functional Ecology 8: 58-68

LUCES Z (1953) Especies de gramíneas nuevas para la ciencia. Boletín de la Sociedad Venezolana de Ciencias Naturales (Venezuela) 80: 3-29.

LUTEYN JL (1999) Paramos: a checklist of plant diversity, geographical distribution, and botanical literature. Memoirs of the New York Botanical Garden 84, The New York Botanical Garden Press, New York, USA. Xx pp.

LUTEYN JL, A CLEEF \& O RANGEL (1992) Plant diversity in paramo: towards a checklist of paramo plants and generic flora. In: Balslev H \& J Luteyn (eds) Paramo: an Andean ecosystem under human influence: 71-84. Academic Press, London, United Kingdom.

MARCHANT R, H BEHLING, J BERRIO, A CLEEF, J DUIVERVOORDEN, H HOOGHIEMSTRA, P KUHRY, B MELIEF, B VAN GEEL, T VAN DER HAMMEN, G VAN REENEN \& M WILLE (2001) Mid- to late-Holocene pollen based biome reconstructions for Colombia. Quaternary Science Reviews 20: 1289-1308.

MÁRQUEZ E (2002) Distribución altitudinal de gramíneas de páramo como respuesta a las rutas metabólicas y los mecanismos de resistencia a las bajas temperaturas. M.Sc. Dissertation, Postgrado en
Ecología Tropical, ICAE, Universidad de Los Andes, Mérida, Venezuela. vi + 93 pp.

MEINZER F \& G GOLDSTEIN (1985) Some consequences of leaf pubescence in the Andean giant rosette plant Espeletia timotensis. Ecology 66: 512-520.

MEINZER F, G GOLDSTEIN \& F RADA (1994) Paramo microclimate and leaf termal balance of Andean giant rosette plants. In: Rundel P A Smith \& F Meinzer (eds) Tropical alpine environments: plant form and function: 45-59. Cambridge University Press, Cambridge, United Kingdom.

MONASTERIO M (1979) El páramo desértico en el altoandino de Venezuela. In: Salgado-Labouriau M (ed) El medio ambiente páramo: 117-146. UNESCO-IVIC, Mérida, Venezuela.

MONASTERIO M (1980a) Las formaciones vegetales de los páramos de Venezuela. In: Monasterio M (ed) Estudios ecológicos en los páramos andinos: 93158. Universidad de Los Andes, Mérida, Venezuela.

MONASTERIO M (1980b) El páramo de Mucubají dentro del cuadro general de los páramos venezolanos. In: Monasterio M (ed) Estudios ecológicos en los páramos andinos: 201-206. Universidad de Los Andes, Mérida, Venezuela.

MONASTERIO M (1986) Adaptive strategies of Espeletia in the Andean desert páramo. In: Vuilleumier F \& M Monasterio (eds) High altitude tropical biogeography: 49-80. Oxford University Press, New York, USA.

MONASTERIO M \& S REYES (1980) Diversidad ambiental y variación de la vegetación en los páramos de los Andes Venezolanos. In: Monasterio M (ed) Estudios ecológicos en los páramos andinos: 47-91. Universidad de Los Andes, Mérida, Venezuela.

MONASTERIO M \& L SARMIENTO (1991) Adaptative radiation of Espeletia in the cold Andean tropics. Trends in Ecology and Evolution 6: 387-391.

POHL R (1980) Family № 15, Gramineae. In: Burger W (ed) Flora costaricensis. Feldiana Botany (USA) 4: 1-608.

RADA F, G GOLDSTEIN, A AZ"CAR \& F MEINZER (1985) Freezing avoidance in Andean giant rosette plants. Plant, Cell and Environment 8: 501-507.

RADA F, G GOLDSTEIN, A AZ"CAR \& F TORRES (1987) Supercooling along an altitudinal gradient in Espeletia schultzii, a caulescent giant rosette species. Journal of Experimental Botany 38: 491497.

RICARDI M, B BRICEÑO \& G ADAMO (1987) Sinopsis de la flora vascular del páramo de Piedras Blancas, Venezuela. Ernstia (Venezuela) 44: 4-14.

RICARDI M, J GAVIRIA \& J ESTRADA (1997) La flora del superpáramo venezolano y sus relaciones fitogeográficas a lo largo de Los Andes. Plántula (Venezuela) 1: 171-187.

ROSENGURTT B, B ARRILLAGA \& P IZAGUIRRE (1970) Gramíneas uruguayas. Museo Nacional de Historia Natural (Uruguay) 18: 1-489.

SAGE R \& T SAGE (2002) Microsite characteristics of Muhlenbergia richardsonis (Trin.) Rydb., an Alpine $\mathrm{C}_{4}$ grass from the White Mountains, California. Oecologia 132: 501-508.

SALGADO-LABOURIAU ML (1978) Cambios climáticos durante el cuaternario tardío paramero y su correlación con las tierras tropicales calientes. In: Salgado-Labouriau M (ed) El medio ambiente páramo: 67-78. UNESCO-IVIC, Caracas, Venezuela

SARMIENTO G (1986) Ecological features of climate in 
high tropical mountains. In: Vuilleumier F \& $\mathrm{M}$ Monasterio (eds) High altitude tropical biogeography: 11-45. Oxford University Press, New York, New York, USA.

SCHUBERT C (1976) Glaciación y morfología periglacial en Los Andes venezolanos noroccidentales. Boletín de la Sociedad Venezolana de Ciencias Naturales (Venezuela) 32: 149-178.

SCHUBERT C (1981) Evolución post-glacial de un valle morrénico, Andes merideños. Acta Científica Venezolana (Venezuela) 32: 111-191.

SCHWARZ A \& R REDMANN (1987) $\mathrm{C}_{4}$ grasses from the boreal forest region of northwestern Canada. Canadian Journal of Botany 66: 2424-2430.

SIMPSON B \& C TODZIA C (1990) Patterns and processes in the development of the high Andean flora. American Journal of Botany 77: 1419-1432.

SKLENÁR̂ P \& P JØRGENSEN (1999) Distribution patterns of paramo plants in Ecuador. Journal of Biogeography 26: 681-691.

SKLENÁR̂ P \& P RAMSAY (2001) Diversity of zonal paramo plant communities in Ecuador. Diversity and Distributions 7: 113-124.

SMITH AP (1994) Introduction to tropical alpine vegetation. In: Rundel P A Smith \& F Meinzer (eds) Tropical alpine environments: plant form and function: 1-19. Cambridge University Press, Cambridge, United Kingdom.

STREET-PERROTT F, Y HUANG, R PERROTT, G EGLINTON, P BARKER, L KHELIFA, D HARKNESS \& D OLAGO (1997) Impact of lower atmospheric carbon dioxide on tropical mountains ecosystems. Science 278: 1422-1426.

TEERI J \& L STOWE (1976) Climatic patterns and the distribution of $\mathrm{C}_{4}$ grasses in North America. Oecologia 23: 1-12.

TER BRAAK C \& L BARENDREGT (1986) Weighted averaging of species indicator values: its efficiency in environmental calibration. Mathematical Biosciences 78: 57-72.

TOVAR O (1993) Las gramíneas (Poaceae) del Perú. Monografías del Real Jardín Botánico (Spain) 13: $1-480$.

VAN DER HAMMEN T (1988) South America. In: Huntley B \& T Webb III (eds) Vegetation history: 307-337. Kluwer Publications, Dordrecht, The Netherlands.

VAN DER HAMMEN T \& A CLEEF (1986) Development of the high Andean paramo flora and vegetation. In: Vuilleumier F \& M Monasterio (eds) High altitude tropical biogeography: 153-201. Oxford University Press, New York, New York, USA. 